\title{
Women and Money: Unique Issues - Finances in a Divorce ${ }^{1}$
}

\author{
Lynda Spence, Martie Gillen, and Diann Douglas²
}

Societal dynamics and their effects on gender roles and family structures underscore a distinct need for financial management education to address the unique issues that women may encounter. This series of EDIS publications, "Women and Money: Unique Issues," encompasses financial management for women across the life cycle and through family transitions. This series focuses on the changes women may encounter throughout their lives and the impact of these changes on their economic status. For the rest of the publications in the series, see http://edis.ifas. ufl.edu/topic_series_women_and_money_unique_issues.

\section{Introduction}

Separation and divorce impact family financial management on multiple levels. Women going through a divorce will have reduced resources and the added expenses of the divorce process. If you are going through a divorce, you should carefully examine the financial factors listed in this publication. Also, you should know that sensible planning may help to lessen the financial stress associated with the transition from marriage to divorce.

In this publication, you will learn how to communicate with your children about your finances during a divorce, create a spending plan, and prioritize your financial goals. Also, you will learn about financial situations unique to a divorce such as dividing up assets, handling joint accounts, receiving alimony and child support payments, and taking care of changes to your insurance, taxes, and retirement accounts.

The first year after the divorce is often when the financial burden is the greatest. The actual financial impact of divorce varies from one case to the next. For example, variations may exist depending on how much money you contributed to the family before the divorce and the ability and willingness of your ex-spouse to make support payments. To learn more about adapting your lifestyle to match the size of your income, read Coping with a Money Crunch: Values, Goals, and Standards (http://edis.ifas.ufl.edu/fy228).

\section{Communicate with Children}

After a divorce, one household budget is now separated into two household budgets. Two households are generally more expensive to maintain than one. Children may understand this concept, or you may need to explain it to them. Studies suggest children do better managing their finances as adults when they are not kept in the dark about money when they are young (Shim et al. 2009).

Generally, children want to be part of a solution if they are given the opportunity. Children feel encouraged when they know their ideas are valued. Have family discussions in which you talk openly about the need for budget

1. This document is FCS7247, one of a series of the Department of Family, Youth and Community Sciences, UF/IFAS Extension. Original publication date: January 2013. Please visit the EDIS website at http://edis.ifas.ufl.edu.

2. Lynda Spence, Extension agent I, UF/IFAS Extension Marion County; Martie Gillen, assistant professor and Family and Consumer Economics for Older Adults specialist, Department of Family, Youth and Community Sciences; and Diann Douglas, County Extension director and Extension agent IV, UF/IFAS Extension Madison County; UF/IFAS Extension, University of Florida, Gainesville, FL 32611. 


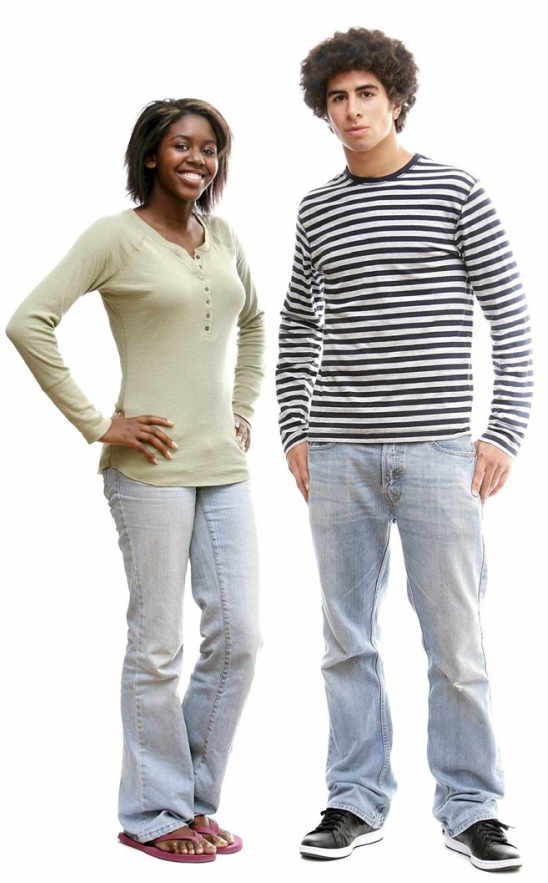

Figure 1. Children usually understand that there may be a financial strain during a divorce. You should include them in discussions as much as you feel comfortable so that they understand the family's financial situation. Credits: http://www.thinkstock.com

adjustments. These will be good opportunities to involve everyone in the solution. Ask your children for suggestions and make some of your own. For example, a four-year-old child can help save on the electricity bill by turning lights out when no one is in the room.

When discussing family finances, the extent of detail you provide will depend on your situation and your level of comfort talking with your children about money. To learn more about how to talk with your family about money, read Coping with a Money Crunch: Family Cooperation (http:// edis.ifas.ufl.edu/fy227).

\section{A Spending Plan}

A spending plan or a budget will help you navigate these changing times. If you do not have much experience managing finances, make sure to familiarize yourself with your finances. Take inventory of all financial documents and records. Collect and copy financial records, including bank account information, mortgage statements, credit card bills, wills, trusts, etc. To help you navigate your changing finances, complete the balance sheet provided in Table 1. Update as needed.

\section{Goal Setting and Prioritizing}

Even if you have a reduced income after a divorce, do not let your financial goals fall away. Enlist support from older children to keep the family on track. For example, ask them to help you complete Table 2 (on page 4). Review and adjust your goals periodically. Always remember to ask your children for input. If you involve them, they will learn an important lesson about goal setting and attainment. Continue to save for short- and long-term goals, even if you have to dramatically reduce what you are setting aside. Small amounts do add up.



Figure 2. Although you may face financial challenges during a divorce, you should set short-term and long-term financial goals. Credits: http://www.thinkstock.com

\section{Track Spending}

Tracking how you spend your money will reveal potential ways to change your habits or reduce spending. If you know how you spend your money, you can make adjustments to put your budget on the right track.

Tracking your spending is essential to help you stay on path to meet financial challenges and achieve financial goals. During the divorce process, you will encounter spending categories unique to this period. Undoubtedly, you will face unforeseen expenses. One-time expenses such as legal fees, moving expenses, and rent or utility deposits may put a strain on your resources. Original estimates may be incorrect. Keeping track will help you make adjustments if this occurs.

Another good reason to track your spending is that sometimes we just spend as needs arise, even when we are aware that this can lead to negative outcomes. You can track electronically by using websites such as Mint.com (http:// www.mint.com) or you can use a written log. The goal is to find a method that works for you. 
Table 1. Balancing Income and Expenses

\begin{tabular}{|c|c|c|c|}
\hline \multicolumn{4}{|c|}{ Step 1: Your monthly income (take-home)* } \\
\hline & Before Divorce & During Divorce & After Divorce \\
\hline Salary, wages & $\$$ & $\$$ & $\$$ \\
\hline Unemployment compensation & $\$$ & $\$$ & $\$$ \\
\hline Child support & $\$$ & $\$$ & $\$$ \\
\hline Social Security Income & $\$$ & $\$$ & $\$$ \\
\hline Food stamps & $\$$ & $\$$ & $\$$ \\
\hline Alimony & $\$$ & $\$$ & $\$$ \\
\hline Other & $\$$ & $\$$ & $\$$ \\
\hline Total Monthly Income (A) & $\$$ & $\$$ & $\$$ \\
\hline \multicolumn{4}{|c|}{ Step 2: Monthly expenses } \\
\hline Emergency fund & $\$$ & $\$$ & $\$$ \\
\hline Housing (mortgage or rent) & $\$$ & $\$$ & $\$$ \\
\hline Utilities (electric, gas, phone, etc.) & $\$$ & $\$$ & $\$$ \\
\hline Food (at home and away) & $\$$ & $\$$ & $\$$ \\
\hline Transportation (gas, car repairs, etc.) & $\$$ & $\$$ & $\$$ \\
\hline $\begin{array}{l}\text { Medical care (doctor, dentist, hospital, } \\
\text { prescriptions) }\end{array}$ & $\$$ & $\$$ & $\$$ \\
\hline Credit payments (loans, credit cards) & $\$$ & $\$$ & $\$$ \\
\hline $\begin{array}{l}\text { Insurance (life, health, disability, car, property, } \\
\text { house) }\end{array}$ & $\$$ & $\$$ & $\$$ \\
\hline $\begin{array}{l}\text { Household operations and maintenance } \\
\text { (repairs, cleaning, laundry supplies, etc.) }\end{array}$ & $\$$ & $\$$ & $\$$ \\
\hline $\begin{array}{l}\text { Clothing and personal care (clothes, shoes, } \\
\text { laundry, toiletries) }\end{array}$ & $\$$ & $\$$ & $\$$ \\
\hline Child care & $\$$ & $\$$ & $\$$ \\
\hline Education and recreation & $\$$ & $\$$ & $\$$ \\
\hline Miscellaneous (gifts, allowances) & $\$$ & $\$$ & $\$$ \\
\hline $\begin{array}{l}\text { Funds set aside for seasonal and occasional } \\
\text { expenses }\end{array}$ & $\$$ & $\$$ & $\$$ \\
\hline Total Monthly Expenses (B) & $\$$ & $\$$ & $\$$ \\
\hline \multicolumn{4}{|c|}{ Step 3: Balance monthly income and expenses } \\
\hline Income $(A) \div$ Expenses $(B)$ & $\$$ & $\$$ & $\$$ \\
\hline \multicolumn{4}{|c|}{$\begin{array}{l}\text { * Because most bills are monthly, it's easiest to look at income and expenses on a monthly basis. You can multiply weekly income by } 4.33 \text { an } \\
\text { bi-weekly income by } 2.17 \text { to convert them to monthly amounts. }\end{array}$} \\
\hline $\begin{array}{l}\text { Adapted from Barbara Wollan and Cynthia Neec } \\
\text { Extension, http://www.extension.iastate.edu/Pu }\end{array}$ & $\begin{array}{l}\text { es, Divorce Matters: Man } \\
\text { lications/PM1720.pdf. }\end{array}$ & ncome and Expenses, Oct & 02, lowa State University \\
\hline
\end{tabular}


Table 2. Saving money for financial goals

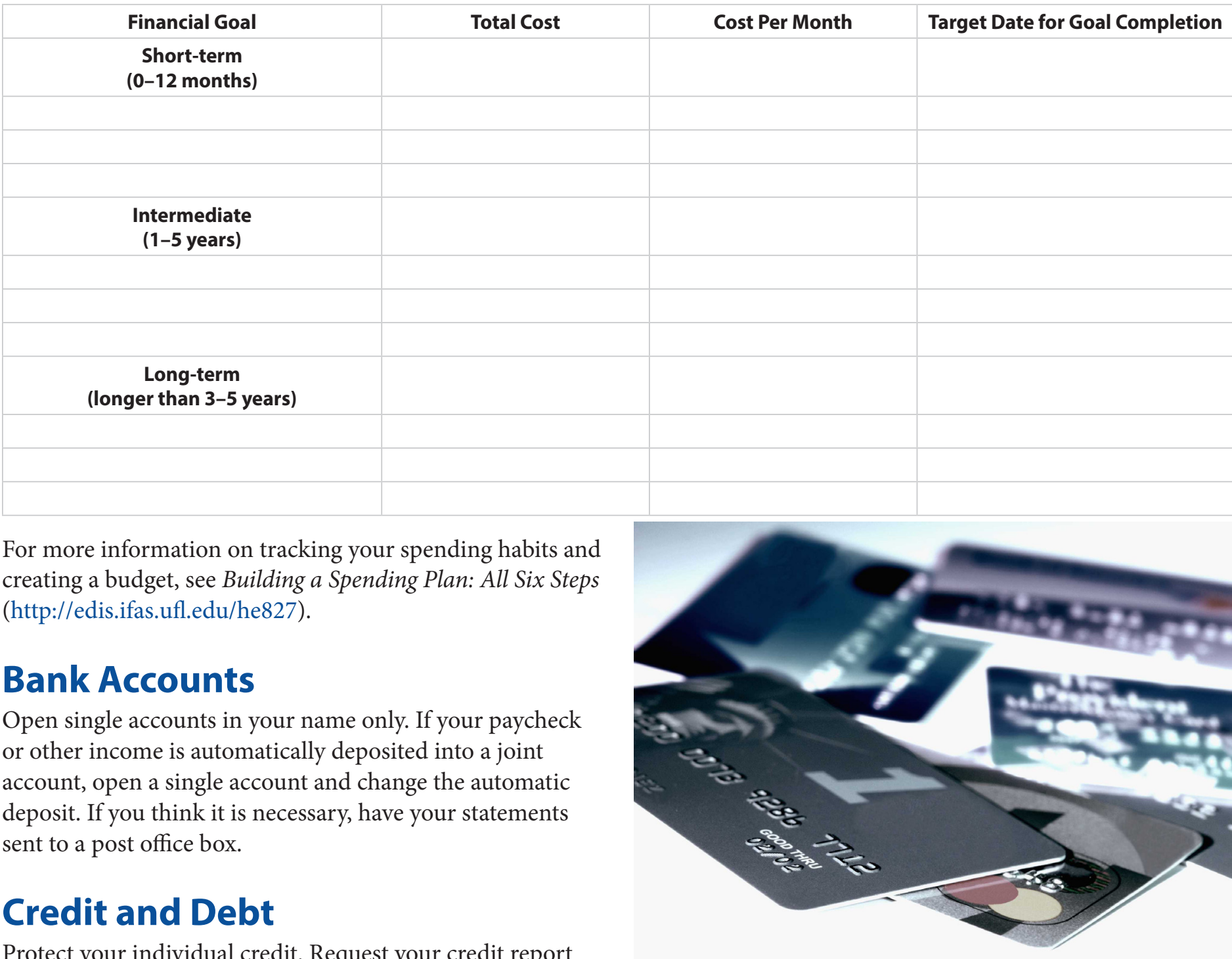

Protect your individual credit. Request your credit report at http://www.annualcreditreport.com. Check your credit report for errors and make the appropriate corrections. To avoid acquiring additional joint debt or suddenly losing shared bank assets during the legal process, close all joint credit and bank accounts. If possible, open individual accounts while you are still married. If you change your name, you can always change the name on the accounts.

The divorce decree has no legal effect on who is responsible to pay which debt. Each person is liable for the full amount of joint accounts until the balance is paid. Creditors can legally go after either or both parties. If the divorce decree orders one divorcing party to pay the debt and that individual does not, you will need to go back to court to have the divorce decree enforced. Meanwhile, if an account becomes delinquent, and you can pay it so that it is current, do so. Remember to keep documentation regarding what you have paid.

Figure 3. If you are going through a divorce, make sure you close all jointly-held credit and bank accounts. You should request your individual credit report and review it for errors and corrections. Credits: Medioimages/Photodisc

Couples may split their debt. An example would be if one person takes the MasterCard and the other takes the Discover; however, that is an agreement between the two of you, not the credit card companies. Be aware that if one person files bankruptcy later down the road, the credit card company will go after the other person.

Any separate debt (for example, a student loan only in your name) will stay with you.

If you are having trouble paying your credit bills on time, contact the National Foundation for Credit Counseling (http://www.nfcc.org/). It is a nonprofit organization founded to help well intentioned consumers get current on their debt. 


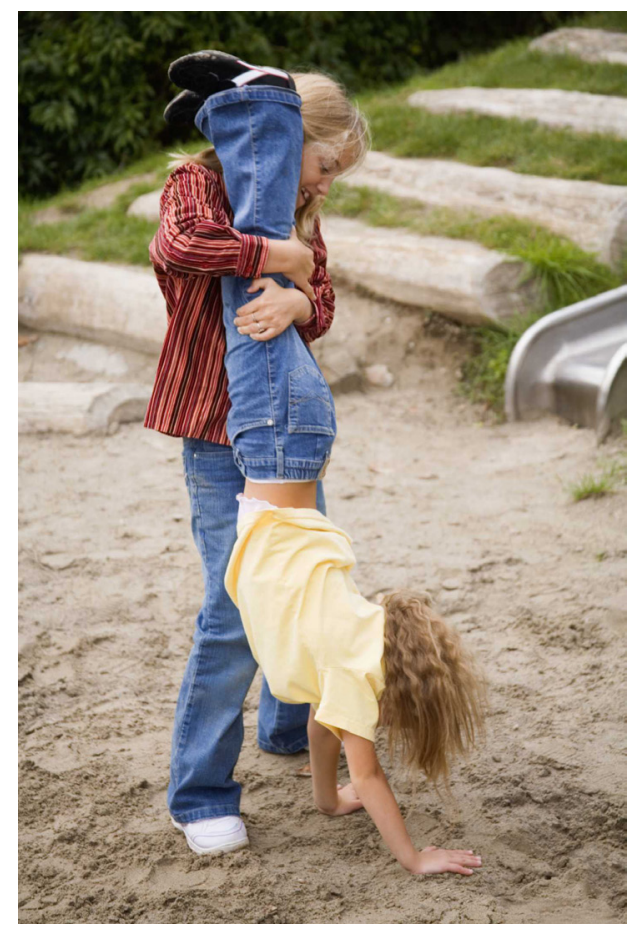

Figure 4. Be aware the child support typically ends when a child reaches the age of 18 . Credits: Jupiterimages

\section{Assets and Liabilities}

Laws on assets and liability vary by state. For example, Arizona, California, Idaho, Louisiana, Nevada, New Mexico, Texas, Washington, and Wisconsin are community property states. These states consider any assets acquired during marriage to be owned equally. The assets will be split $50 / 50$ in divorce.

In non-community property states, equitable distribution laws govern how a couple's assets will be divided. Some states only divide assets acquired during the marriage, while others consider everything available for divvying up. In some states, the distribution laws take on a punitive aspect by considering which partner is most at fault for the marriage's breakup.

Florida is a separate property or equitable distribution state. All marital assets and all marital liabilities will be "equitably" divided. Equitable means fair - it does NOT mean 50/50, although that is often the starting point. For example, if you divorce, the judge has discretion and can award marital property to whichever spouse he or she thinks should receive it. Non-marital property stays with its owner, even in divorce.

Any asset acquired and any liability incurred during the marriage through the use of marital funds or marital labor are either a marital asset or marital liability. Savings, pensions, 401(k)s, IRAs, vacation homes, stocks and bonds, mutual funds, airline miles, credit card accounts, mortgages, automobiles, and auto loans, etc., are all examples of marital assets and liabilities.

\section{Child Support}

Every state relies on a standardized formula to determine a minimum level of child-support payments. Courts can award more if they choose. Federal law requires states to review child-support agreements from time to time and adjust for inflation or changes in parents' income. Child support typically ends when the child reaches 18 . Childsupport payments are neither tax-deductible by the payer nor taxable as income to the recipient.

\section{Alimony}

Alimony is ordered by a court for a limited time on the basis of a spouse's need or entitlement and the other spouse's ability to pay. It is treated as a tax-deductible expense for the person who pays it and taxable income for the person who receives it.

\section{Taxes}

If you do not address it, your divorce settlement could have a costly effect on your taxes. You may need to consult a tax professional. Property and assets may be subject to a capital-gains tax of up to $40 \%$ if sold, depending on any given year's tax code. Your marital status as of December 31 controls your filing status for that year. If you were still married on December 31, you may want to file a joint return because this could save you money. If you were divorced before December 31 and you qualify, you will likely want to file as head of household. Decide who gets to claim the

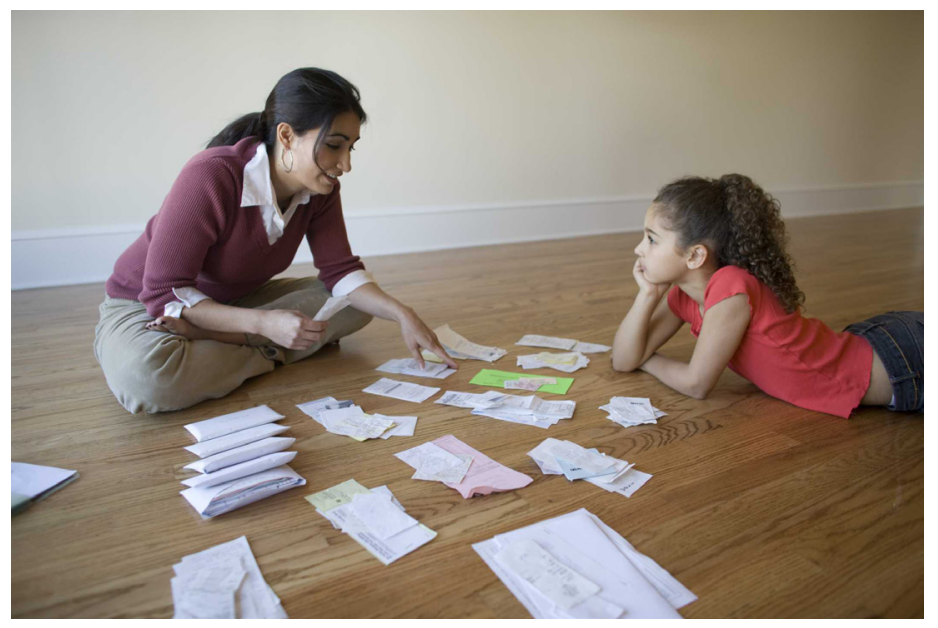

Figure 5. You should be aware that your divorce settlement can affect your taxes. Consult with a tax professional for advice on handling your taxes immediately after a divorce. Credits: David Sacks 
children as exemptions on the tax return and consider how that decision may affect the eligibility of funds for college.

Learn about the Earned Income Tax Credit (EITC) for heads of household with dependents. Read the instructions for Form 1040 about dependents, withholding exemptions, and support as it relates to custody arrangements and the EITC. For example, as a single parent with a modified adjusted gross income less than $\$ 45,060$ per year, if you file as head of household, you may be eligible for the Earned Income Tax Credit of what to date has been up to $\$ 1,000$ for each child under the age of 17 . To learn more, read http://www.eitc.irs.gov/central/abouteitc/. For college-aged children, you may qualify for applicable Tuition and Fees credits or deductions; see http://www.irs.gov/taxtopics/ tc 457.html for more information. You can also read this helpful publication on tax filing, separation, and divorce: http://www.irs.gov/publications/p504/index.html.

\section{Insurance}

Review your insurance policies to make sure they fit your new circumstances. Delete your ex-spouse and change your marital status to single where needed. Change your beneficiaries on your insurance policies. Despite what your divorce decrees, if you don't change beneficiaries on all documents, your ex-spouse could receive money in the event of your untimely demise.

\section{Life Insurance}

Ensure that your ex-spouse has life insurance and that he or she doesn't allow it to lapse. Know who is listed as the beneficiary (or beneficiaries) and how much your children would collect in the event of his or her death. Ask your attorney about having this spelled out in the divorce settlement.

\section{Health Insurance \\ YOUR HEALTH INSURANCE}

Whenever possible, make sure you are covered. If you are currently unable to afford health insurance, inquire at your county health department. The health department may have health programs you can benefit from and charges are generally on a sliding scale based on your income. Include health coverage as a financial goal. It is important to have health coverage.

\section{YOUR CHILDREN'S INSURANCE}

If neither party has health insurance, the parent who is awarded custody should ask that the expense of insurance be factored into the amount of child support paid. Under the Consolidated Omnibus Budget Reconciliation (COBRA), if your spouse's employer has 20 or more employees, the employer must allow the other spouse to have a policy with its health insurer for three years following a divorce.

Florida offers health insurance, called Florida KidCare (http://www.floridakidcare.org/), for children from birth through age 18. Children can be eligible even if one or both parents are working. Florida KidCare includes four different parts. When you apply for the insurance, Florida KidCare will check which part your child may qualify for based on age and family income:

- MediKids: Children ages 1 through 4.

- Healthy Kids: Children ages 5 through 18.

- Children's Medical Services Network: Children birth through age 18 who have special health care needs.

- Medicaid: Children birth through age 18. A child who has other health insurance may still qualify for Medicaid.

\section{DISABILITY INSURANCE}

Your health is just as important as your children's. If something happens to you and you cannot work, will your emergency fund cover the shortage? What if there is no emergency fund? Disability Income Insurance (or DI) is a separate policy you purchase; it is not health insurance.

A claim may be stated as a percent of income or a set dollar amount. The policy defines how much and how soon after you are disabled payments will begin and when they stop. Benefit periods may depend on whether disability was caused by accident or illness. The longer the benefit period, the higher the premium will be.

Find out what type of disability insurance is available through your employer, or explore other options for coverage. Ask your attorney to include in the settlement that your former spouse is covered by a disability policy. This will be important protection if you or your children are counting on him for income.

If you have to reduce coverage to make ends meet, slowly add funds for additional protection into your budget as your resources allow. You may want to include this as a financial goal. 


\section{Retirement}

Update your beneficiary information. Keep contributing to your retirement account(s), and open new ones if necessary. Know how your retirement accounts can be used and how they will be taxed. For example, if you cash out a 401(k) or plan to give the money to your ex, the IRS considers that a taxable distribution and you will have to pay the taxes. You can avoid these taxes by having the transfer accomplished under a qualified domestic relations order (QDRO) through the court system. A QDRO will give your ex-spouse the right to the funds and relieves you of the tax burden.

\section{Social Security}

If you change your last name, don't forget to update your W-4 and also update your information with the Social Security Administration.

\section{Estate Planning}

Make sure to update your will, health care directives, and trusts.

\section{References}

Shim, S., J.J. Xiao, B. Barber, and A.C. Lyons. 2009.

"Pathways to Life Success: A Conceptual Model of Financial Well-Being for Young Adults." Journal of Applied Developmental Psychology 30(6):708-23.

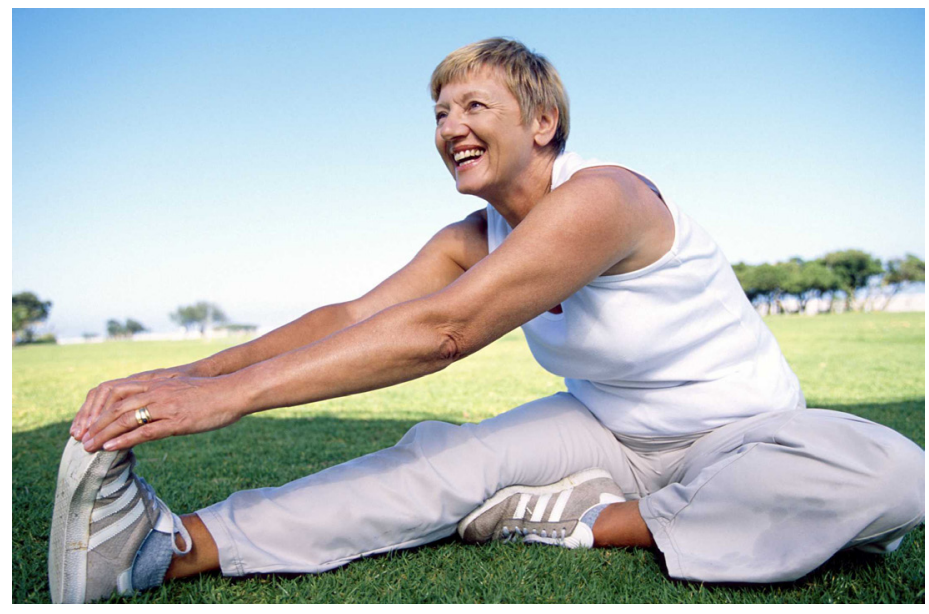

Figure 6. Make sure you know how money in your retirement accounts can be used and how they will be taxed if they are part of a divorce settlement. Credits: Goodshot 